\title{
Analisis Pertumbuhan Tanaman Kayu Putih (Melaleuca cajuputi sub sp. cajuputi) Pada Kawasan Hutan Lindung Dusun Malimbu Dan Dusun Badung Resort Malimbu KPHL Rinjani Barat
}

(Growth Analysis of Cajuputi (Melaleuca cajuputi sub sp. cajuputi) in the Area of Protected Forest in Malimbu and Badung Sub Village Resort of Malimbu PFMU of Rinjani Barat)

\author{
Ida Bagus Wedhana ${ }^{1}$, Muhamad Husni Idris ${ }^{1}$, Rato Firdaus Silamon ${ }^{1}$ \\ ${ }^{1}$ Program Studi Kehutanan, Universitas Mataram \\ JI Majapahit No 62, Mataram, NTB \\ Email: husni id98@yahoo.com
}

\begin{abstract}
This research was aimed to determine the characteristics of land that affect the differences in growth of cajuputi in Malimbu and Badung and determine the class land suitability of cajuputi in Malimbu and Badung. This research was conducted in Malimbu and Badung subvillage resort of Malimbu PFMU of Rinjani Barat. The parameters measured were the growth of cajuputi, elevation above sea level, the temperature, and the characteristics of soil (soil texture, soil water content, effective depth, bulk density, soil porosity and soil temperature). The result of this study shows that 1). The average diameter, height, volume and number of plants of cajuputi of 22 months age in Badung was $3,33 \mathrm{~cm}, 3,29 \mathrm{~m}, 2.355,83 \mathrm{~cm}^{3}$ and 32 plants/plot, respectively. While in Malimbu was $1,43 \mathrm{~cm}, 1,87 \mathrm{~m}, 241,85 \mathrm{~cm}^{3}$ and 22 plants/plot, respectively; 2). The growth of diameter of cajuputi at $95 \%(\alpha=0.05)$ significance level was sand fraction, soil temperature, effective depth, elevation above sea level, while on the growth of height of cajuputi was sand fraction, bulk density, and effective depth; 3). The suitability of actual land for cajuputi in Malimbu was categorized as class $N_{1} r$ with the limited factors of root media (soil drainage), while that in Badung was categorized as class $S_{3} w$ and $S_{3} w r$ with the limited factors of water availability (dry month) and root media (soil drainage).
\end{abstract}

Keywords : Forest, Land Evaluation, Cajuputi (Melaleuca Cajuputi Sub Sp. Cajuputi)

\section{Abstrak}

Tujuan penelitian ini adalah untuk mengetahui faktor karakteristik lahan yang mempengaruhi perbedaan pertumbuhan kayu putih di Malimbu dan Badung dan menentukan kelas kesesuaian lahan kayu putih di Malimbu dan Badung. Penelitian ini dilakukan di kawasan hutan lindung Dusun Malimbu dan Badung Resort Malimbu KPHL Rinjani Barat. Parameter yang diukur adalah pertumbuhan kayu putih meliputi diameter, tinggi dan volume, serta faktor lingkungan meliputi ketinggian tempat, suhu udara, dan sifat fisika tanah (tekstur tanah, kadar air tanah, kedalaman efektif, bulk density, porositas tanah dan suhu tanah). Hasil penelitian menunjukkan bahwa : 1). Rata-rata diameter, tinggi, volume dan jumlah tanaman kayu putih umur 22 bulan di Badung sebesar $3,33 \mathrm{~cm}, 3,29 \mathrm{~m}, 2.355,83 \mathrm{~cm}^{3}$ dan 32 tanaman/plot, sedangkan di Malimbu sebesar $1,43 \mathrm{~cm}, 1,87 \mathrm{~m}, 241,85 \mathrm{~cm}^{3}$ dan 22 tanaman/plot; 2). Faktor yang berpengaruh nyata pada taraf toleransi $95 \%(\alpha=0,05)$ terhadap diameter kayu putih adalah fraksi pasir, suhu tanah, kedalaman efektif dan ketinggian tempat, sedangkan terhadap tinggi kayu putih adalah fraksi pasir, bulk density dan kedalaman efektif; 3). Kesesuaian lahan 
aktual kayu putih di Malimbu tergolong kelas $N_{1} r$ dengan faktor pembatas media perakaran (drainase tanah), sedangkan di Badung tergolong kelas $\mathrm{S}_{3} \mathrm{~W}$ dan $\mathrm{S}_{3} \mathrm{wr}$ dengan faktor pembatas ketersediaan air (bulan kering) dan media perakaran (drainase tanah).

Kata Kunci : Hutan, Evaluasi Lahan, Kayu Putih (Melaleuca cajuputi sub sp. Cajuputi)

\section{Pendahuluan}

Pengelolaan hutan untuk memperoleh manfaat yang sebesar-besarnya pada tingkat tapak dilaksanakan oleh KPH (Kesatuan Pengelolaan Hutan). Salah satu unit kesatuan pengelolaan hutan lindung di wilayah Nusa Tenggara Barat adalah KPHL Rinjani Barat. Atas dasar hasil identifikasi dan inventarisasi hutan, pembagian unit dalam KPH ditetapkan menjadi beberapa wilayah kerja (Resort), salah satunya adalah Resort Malimbu. Pengelolaan kawasan hutan Resort Malimbu ini memiliki luasan $\pm 3.760,17 \mathrm{Ha}$ (KPHL Rinjani Barat, 2011).

Kawasan hutan Lindung Resort Malimbu sejak tahun 2012 merupakan lokasi reboisasi pengkayaan hutan Lindung wilayah KPHL Rinjani Barat dengan jenis kayu putih (Melaleuca cajuputi sub sp. cajuputi). Kegiatan persemaian, penanaman dan pemeliharaan kayu putih dilaksanakan secara swakelola bersama masyarakat atau kelompok tani hutan di beberapa titik lokasi (KPH Rinjani Barat, 2012).

Seiring perkembangannya, tanaman kayu putih tersebut menunjukkan perbedaan kualitas pertumbuhan pada umur 22 bulan yaitu di Dusun Malimbu dengan kualitas pertumbuhan yang kurang baik, sedangkan di Dusun Badung dengan kualitas pertumbuhan yang baik. Evaluasi keberhasilan tanaman dan analisa faktor lingkungan fisik penting dilakukan untuk mengetahui karakteristik lahan mana yang berpengaruh terhadap pertumbuhan kayu putih, agar tercapai pengelolaan hutan tanaman kayu putih yang lebih baik. Tujuan dari penelitian ini adalah untuk mengetahui faktor karakteristik lahan yang mempengaruhi perbedaan pertumbuhan Kayu Putih dan menentukan Kelas kesesuaian lahan Kayu Putih di Malimbu dan Badung.

\section{Metode}

\section{Lokasi dan Waktu Penelitian}

Penelitian ini dilaksanakan di Kawasan Hutan Lindung Dusun Malimbu dan Dusun Badung Desa Malaka Resort Malimbu KPHL Rinjani Barat dan dilaksanakan pada Bulan Desember 2014 sampai dengan Bulan Mei 2015.

\section{Penentuan Sampel dan Teknik Pengumpulan Data}

Lokasi penelitian ditetapkan dengan metode Purposive Sampling yaitu teknik pengambilan sampel atau sumber data dengan pertimbangan tertentu (Sugiyono, 2013). Sampel ditetapkan secara Simple Random Sampling yaitu dimana dalam memilih sampel dari $\mathrm{n}$ unit, setiap kombinasi $\mathrm{n}$ unit yang mungkin mempunyai kesempatan yang sama untuk dipilih (Simon, 2007), sehingga diperoleh 6 titik lokasi yang menjadi plot ukur penelitian yang terdiri dari 3 plot di Malimbu dan 3 plot di Badung dengan ukuran plot $20 \mathrm{~m} \times 20 \mathrm{~m}$. Gambar 1 berikut ini merupakan gambaran dari titik-titik lokasi pengambilan sampel penelitian. 


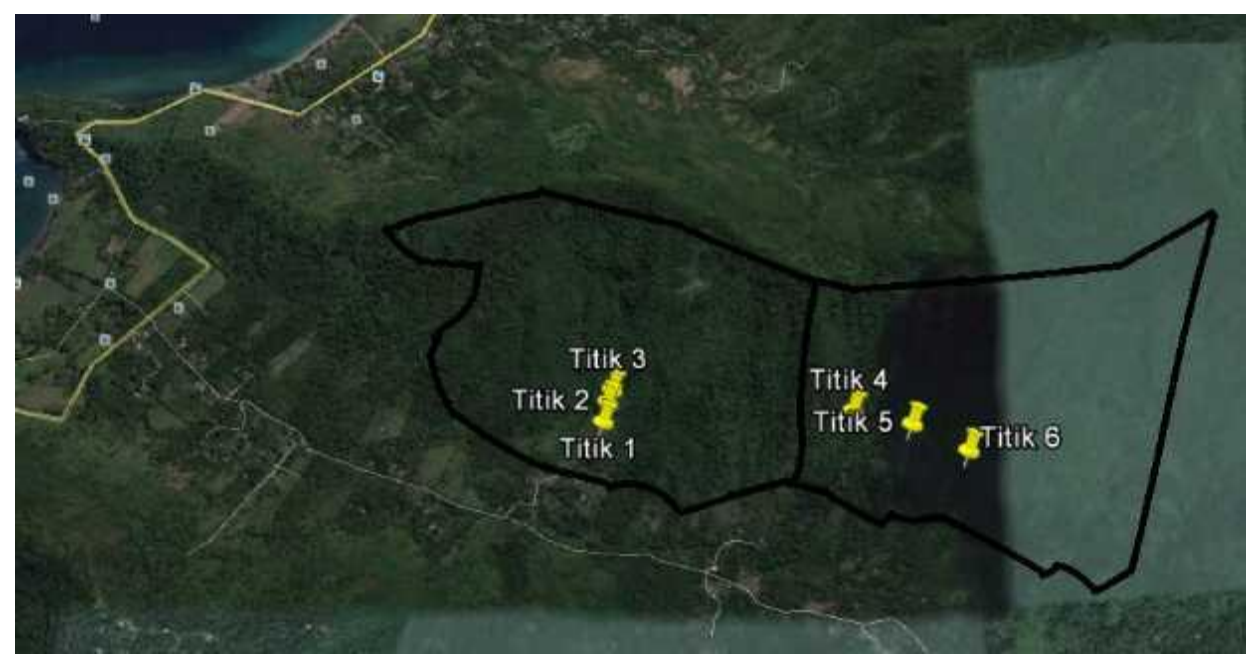

Gambar 1. Peta Kawasan Dusun Malimbu dan Dusun Badung Resort Malimbu KPHL Rinjani Barat

Figure 1. Map of Dusun Malimbu and Badung Resort Malimbu KPHL Rinjani Barat

Pengumpulan data dilakukan dengan teknik observasi yaitu dengan mengadakan pengamatan secara langsung terhadap masalah yang diteliti, dengan maksud untuk membandingkan keterangan yang diperoleh dengan kenyataan (Arikunto, 2006).

\section{Parameter Pengukuran}

Parameter yang diukur dalam penelitian ini terdiri dari parameter pertumbuhan meliputi diameter yang diukur dengan alat pita ukur, parameter tinggi diukur dengan alat Suunto Clinometer dan volume tanaman, ketinggian tempat yang diukur dengan alat GPS, suhu udara diukur dengan alat thermohigrometer, tekstur tanah (fraksi pasir, debu dan liat) diukur dengan metode pipet, kadar air tanah diukur dengan metode gravimetrik, bulk density dan porositas tanah diukur dengan metode ring sampel, kedalaman efektif diukur dengan alat bor tanah dan meteran, dan suhu tanah diukur dengan alat thermometer air raksa.

\section{Analisis Data}

Analisis data yang digunakan dalam penelitian ini adalah analisis regresi linear berganda ditujukan untuk menentukan hubungan linear antar variabel bebas karakteristik lahan $(X)$ terhadap parameter pertumbuhan (diameter, tinggi serta volume) tanaman kayu putih ( $Y$ ), dimana pengolahan data dilakukan dengan menggunakan program SPSS 16 dengan metode Stepwise dan analisis komparasi deskriptif yaitu pencocokan antara karakteristik lahan lokasi penelitian dengan kriteria kesesuaian lahan untuk tanaman kayu putih yang telah ditentukan untuk menentukan kelas kesesuaian lahan di lokasi penelitian.

\section{Hasil Dan Pembahasan}

\section{Ketinggian Tempat dan Suhu Udara}

Hasil analisis menunjukkan bahwa ketinggian tempat di Badung dengan rata-rata 164,33 $\mathrm{m}$ dpl lebih tinggi daripada di Malimbu dengan rata-rata $89 \mathrm{~m}$ dpl. Menurut Ritung et al. (2007), ketinggian tempat mempengaruhi perubahan suhu udara. Semakin tinggi suatu tempat, maka suhu udara di tempat tersebut akan semakin rendah dan sebaliknya. Suhu udara rata-rata pada 
bulan Desember tahun 2014 di Badung sebesar $27,90^{\circ} \mathrm{C}$ lebih rendah daripada di Malimbu sebesar $29,21^{\circ} \mathrm{C}$.

Ketinggian tempat dan Suhu Udara

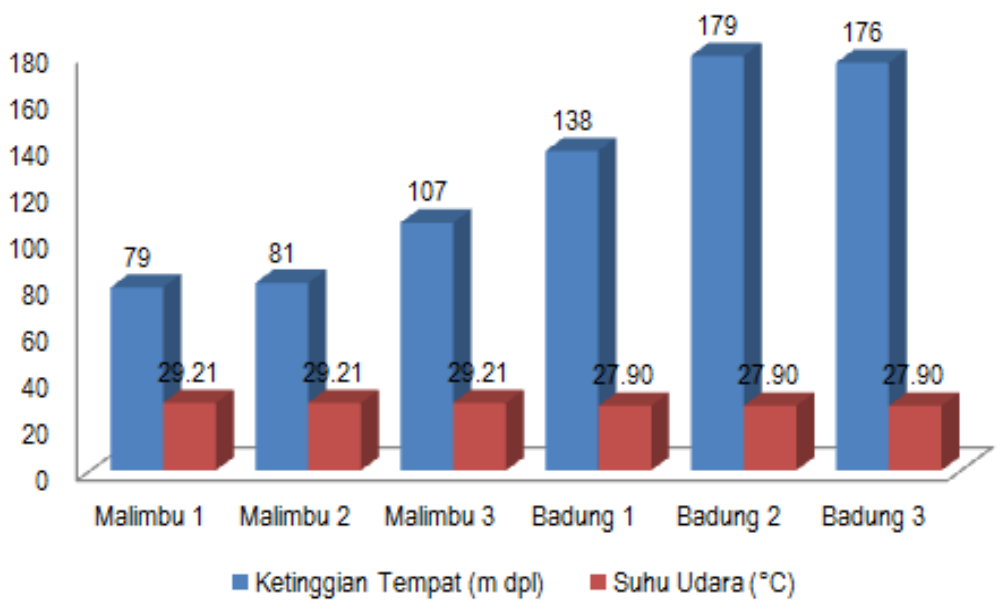

Gambar 2. Hasil Pengukuran Ketinggian Tempat dan Suhu Udara di Malimbu dan Badung Figure 2. Result of Measurement of Altitude Place and Air Temperature in Malimbu and Badung

\section{Jenis Tanah}

Tabel 1. Jenis Tanah Pada Hutan Malimbu (M) dan Badung (B) Table 1. Type of Land in Malimbu (M) and Badung Forests (B)

\begin{tabular}{ccc} 
No. Plot Ukur & \multicolumn{2}{c}{ Jenis Tanah } \\
\cline { 2 - 3 } & $\mathbf{M}$ & $\mathbf{B}$ \\
\hline 1 & Entisol & Inceptisol \\
2 & Entisol & Inceptisol \\
3 & Entisol & Inceptisol \\
\hline
\end{tabular}

Tabel 1 di atas menunjukkan bahwa tanah Malimbu merupakan jenis tanah Entisol karena bertekstur kasar (pasir berlempung), memiliki solum yang lebih dangkal, terdapat pada bukit pasir pantai, mempunyai permeabilitas atau drainase tanah yang cepat dan daya menahan air yang sangat rendah, serta bahan organik dan kadar air tanah yang rendah. Sedangkan, tanah Badung merupakan jenis tanah Inceptisol karena bertekstur liat dan lempung liat berpasir, melalui pengamatan langsung di lapangan kandungan liat pada horizon B lebih tinggi daripada horizon di atasnya, kandungan organiknya sedang sampai tinggi yang ditunjukkan dengan kelas drainase tanah terhambat dan agak terhambat sehingga daya mengikat air cukup tinggi, serta merupakan tanah yang cukup subur. 


\section{Sifat Fisik Tanah}

Tabel 2. Data Karakteristik Sifat Fisik Tanah Pada Hutan Malimbu

Table 2. Characteristic Data of Soil Physical Properties in Malimbu Forest

\begin{tabular}{|c|c|c|c|c|c|c|c|c|c|c|c|}
\hline \multirow{2}{*}{$\begin{array}{l}\text { No. Plot } \\
\text { Ukur }\end{array}$} & \multicolumn{3}{|c|}{ Fraksi Tanah (\%) } & \multirow{2}{*}{ Tekstur } & \multicolumn{4}{|c|}{ Kadar Air Tanah (\%) } & \multirow{2}{*}{$\begin{array}{c}\text { Drainase } \\
\text { Tanah } \\
\end{array}$} & \multirow{2}{*}{$\begin{array}{l}\text { Kedalaman } \\
\text { Efektif (cm) }\end{array}$} & \multirow{2}{*}{$\begin{array}{c}\text { Suhu } \\
\text { Tanah } \\
\left({ }^{\circ} \mathrm{C}\right) \\
\end{array}$} \\
\hline & Liat & Debu & Pasir & & KL & TLP & AT & KA & & & \\
\hline 1 & 7,80 & 8,20 & 84,00 & $L S$ & 36,04 & 2,14 & 33,90 & 14,55 & Cepat & 56 & 27,25 \\
\hline 2 & 10,40 & 8,27 & 81,33 & $L S$ & 35,56 & 1,67 & 33,89 & 12,91 & Cepat & 60 & 27 \\
\hline 3 & 7,80 & 8,20 & 84,00 & $L S$ & 35,21 & 1,71 & 33,49 & 11,30 & Cepat & 65 & 27 \\
\hline $\begin{array}{l}\text { Rata- } \\
\text { rata }\end{array}$ & 8,67 & 8,22 & 83,11 & $L S$ & 35,60 & 1,84 & 33,76 & 12,92 & Cepat & 60,33 & 27,08 \\
\hline
\end{tabular}

Tabel 3. Data Karakteristik Sifat Fisik Tanah Pada Hutan Badung

Table 3. Characteristic Data of Soil Physical Characteristic in Badung Forest

\begin{tabular}{|c|c|c|c|c|c|c|c|c|c|c|c|}
\hline \multirow{2}{*}{$\begin{array}{l}\text { No. Plot } \\
\text { Ukur }\end{array}$} & \multicolumn{3}{|c|}{ Fraksi Tanah (\%) } & \multirow{2}{*}{$\underset{\mathbf{r}}{\text { Tekstu }}$} & \multicolumn{4}{|c|}{ Kadar Air Tanah (\%) } & \multirow{2}{*}{$\begin{array}{c}\text { Drainase } \\
\text { Tanah }\end{array}$} & \multirow{2}{*}{$\begin{array}{l}\text { Kedalaman } \\
\text { Efektif (cm) }\end{array}$} & \multirow{2}{*}{$\begin{array}{l}\text { Suhu } \\
\text { Tanah } \\
\left({ }^{\circ} \mathrm{C}\right)\end{array}$} \\
\hline & Liat & $\begin{array}{c}\text { Deb } \\
\text { u }\end{array}$ & Pasir & & $\mathrm{KL}$ & TLP & AT & KA & & & \\
\hline & 44,2 & 19,8 & 36,0 & & 42,3 & 12,0 & 30,3 & 27,2 & & & \\
\hline 1 & $\begin{array}{c}0 \\
33,8\end{array}$ & $\begin{array}{c}0 \\
16,8\end{array}$ & $\begin{array}{c}0 \\
49,3\end{array}$ & C & $\begin{array}{c}9 \\
41,8\end{array}$ & 0 & $\begin{array}{c}8 \\
32,4\end{array}$ & $\begin{array}{c}4 \\
26,3\end{array}$ & Terhambat & 86 & 25,25 \\
\hline 2 & $\begin{array}{c}0 \\
31,2\end{array}$ & $\begin{array}{c}7 \\
14.1\end{array}$ & $\begin{array}{c}3 \\
54.6\end{array}$ & $S C L$ & $\begin{array}{c}7 \\
38.7\end{array}$ & 9,45 & $\begin{array}{c}2 \\
29.7\end{array}$ & $\begin{array}{r}7 \\
24.9\end{array}$ & Agak Terhambat & 91 & 26,25 \\
\hline 3 & 0 & 3 & 7 & $S C L$ & 5 & 8,98 & 7 & 5 & Agak Terhambat & 82 & 26,25 \\
\hline $\begin{array}{l}\text { Rata- } \\
\text { rata }\end{array}$ & $\begin{array}{c}36,4 \\
0\end{array}$ & $\begin{array}{c}16,9 \\
3\end{array}$ & $\begin{array}{c}46,6 \\
7\end{array}$ & $S C L$ & $\begin{array}{c}41,0 \\
0\end{array}$ & $\begin{array}{c}10,1 \\
4\end{array}$ & $\begin{array}{c}30,8 \\
6\end{array}$ & $\begin{array}{c}26,1 \\
9\end{array}$ & $\begin{array}{c}\text { Agak } \\
\text { Terhambat }\end{array}$ & 86,33 & 25,92 \\
\hline
\end{tabular}

\section{Tekstur Tanah}

Tabel 2 di atas menunjukkan bahwa tekstur tanah di Malimbu yaitu Loamy Sand (pasir berlempung). Sedangkan, Tabel 3 di atas menunjukkan bahwa tekstur tanah di Badung yaitu Clay (liat) dan Sandy Clay Loam (lempung liat berpasir). Menurut Hanafiah (2005), apabila permeabilitas atau drainase tanah (kecepatan perembesan air dalam tanah) dikaitkan dengan tekstur tanah maka kelas drainase cepat merupakan karakter tanah bertekstur kasar atau tanah berpasir, sedangkan kelas drainase lambat atau terhambat merupakan karakter tanah bertekstur halus atau tanah berliat, serta kelas drainase sedang atau agak terhambat merupakan karakter tanah bertekstur sedang atau tanah berlempung.

\section{Kadar Air Tanah}

Tabel 2 dan Tabel 3 di atas menunjukkan bahwa terdapat perbedaan dari seluruh nilai rata-rata kadar air tanah kapasitas lapang (KL), titik layu permanen (TLP) dan air tersedia (AT) serta kadar air tanah kering angin (KA) selama 7 hari tidak hujan di Malimbu dan Badung. Hal ini disebabkan oleh tekstur tanah Badung (liat dan lempung liat berpasir) lebih halus daripada tekstur tanah Malimbu (pasir berlempung). Menurut Hanafiah (2005), semakin tidak porous tanah (didominasi liat) maka air yang ada pada tanah tersebut tidak mudah hilang. Hal ini terkait dengan pengaruh tekstur terhadap proporsi bahan koloidal, ruang pori dan luas permukaan adsorptif, yang semakin halus teksturnya akan semakin banyak kapasitas-simpanan airnya.

\section{Kedalaman efektif}

Tabel 2 dan Tabel 3 di atas menunjukkan bahwa kedalaman efektif di Malimbu dengan rata-rata $60,33 \mathrm{~cm}$ lebih dangkal daripada di Badung dengan rata-rata $86,33 \mathrm{~cm}$. Menurut 
Hardjowigeno (2011), tanah dengan kedalaman efektif dangkal akan menyebabkan terhambatnya perkembangan akar tanaman dan tanah dengan kedalaman efektif dalam akan mempunyai aerasi dan drainase yang baik, serta mampu menyokong perkembangan akar dan tanaman dengan baik.

\section{Suhu Tanah}

Tabel 2 dan Tabel 3 di atas menunjukkan bahwa suhu tanah rata-rata harian dari semua plot ukur sebesar $25,92^{\circ} \mathrm{C}$ di Badung lebih rendah daripada di Malimbu sebesar $27,08^{\circ} \mathrm{C}$. Menurut Syafei (1990), suhu tanah yang rendah mempengaruhi rata-rata penguapan air dan pertumbuhan akar. Suhu tanah yang rendah mengurangi kecepatan penguapan air oleh akar. Tumbuhan mampu hidup pada rentangan suhu tertentu sesuai dengan kemampuan fisiologinya. Suhu tanah berpengaruh terhadap pertumbuhan akar serta kondisi air.

\section{Bulk Density dan Porositas Tanah}

Tabel 4. Hasil Analisis Bulk Density dan Porositas Tanah Pada Hutan Malimbu (M) dan Badung (B) Table 4. Bulk Density and Soil Porosity Analysis Results In Malimbu (M) and Badung Forests (B)

\begin{tabular}{|c|c|c|c|c|c|c|c|c|}
\hline \multirow[t]{2}{*}{ No. Plot Ukur } & \multicolumn{2}{|c|}{$\begin{array}{l}\text { Kedalaman } \\
\text { (cm) }\end{array}$} & \multicolumn{2}{|c|}{$\begin{array}{c}\text { Bulk Density } \\
\qquad\left(\mathrm{g} / \mathrm{cm}^{3}\right)\end{array}$} & \multicolumn{2}{|c|}{$\begin{array}{c}\text { \% Bahan Padat } \\
\text { Tanah }\end{array}$} & \multicolumn{2}{|c|}{$\begin{array}{c}\text { Porositas Tanah } \\
\text { (\%) }\end{array}$} \\
\hline & M & B & $M$ & B & $M$ & B & $M$ & B \\
\hline \multirow[t]{3}{*}{1} & $0-8$ & $0-28$ & 0.85 & 1.38 & 32.06 & 52.20 & 67.94 & 47.80 \\
\hline & $18-37$ & $28-57$ & 0.88 & 1.50 & 33.19 & 56.68 & 66.81 & 43.32 \\
\hline & $37-56$ & $57-86$ & 0.81 & 1.49 & 30.59 & 56.26 & 69.41 & 43.74 \\
\hline \multirow[t]{3}{*}{2} & $0-20$ & $0-30$ & 0.82 & 1.25 & 31.11 & 47.10 & 68.89 & 52.90 \\
\hline & $20-40$ & $30-60$ & 0.83 & 1.25 & 31.28 & 47.12 & 68.72 & 52.88 \\
\hline & $40-60$ & $60-91$ & 0.80 & 1.38 & 30.33 & 51.97 & 69.67 & 48.03 \\
\hline \multirow[t]{3}{*}{3} & $0-21$ & $0-27$ & 0.78 & 1.06 & 29.48 & 40.11 & 70.52 & 59.89 \\
\hline & $21-43$ & $27-54$ & 0.76 & 1.09 & 28.51 & 41.26 & 71.49 & 58.74 \\
\hline & $43-65$ & $54-82$ & 0.76 & 1.16 & 28.70 & 43.66 & 71.30 & 56.34 \\
\hline Rata-rata & & & 0.81 & 1.28 & 30.58 & 48.48 & 69.42 & 51.52 \\
\hline
\end{tabular}

Tabel 4 di atas menunjukkan bahwa semakin padat suatu tanah maka semakin tinggi bulk density, yang berarti makin sulit meneruskan air atau ditembus akar tanaman. Porositas tanah di Malimbu lebih tinggi daripada di Badung. Hal ini dikarenakan tanah Malimbu bertekstur pasir berlempung atau didominasi pasir yang memiliki pori-pori makro (kasar). Menurut Hardjowigeno (2003), pori-pori tanah adalah bagian yang tidak terisi bahan padat tanah (terisi oleh udara dan air). Pori-pori tanah dapat dibedakan menjadi pori-pori kasar (macro pore) dan pori-pori halus (micro pore). Pori-pori kasar berisi udara atau air gravitasi (air yang mudah hilang karena gaya gravitasi), sedangkan pori-pori halus berisi air kapiler atau udara. Tanah-tanah pasir mempunyai pori-pori kasar lebih banyak daripada tanah liat. Tanah dengan banyak pori-pori kasar akan sulit menahan air sehingga tanaman mudah kekeringan. Dalam kaitannya dengan tekstur, biasanya tanah yang memiliki tekstur kasar akan memiliki ruang pori (porositas) yang lebih banyak dibandingkan dengan tanah yang bertekstur lebih halus. Tanah yang bertekstur kasar, seperti tanah pasir, akan memiliki ruang pori yang didominasi oleh pori yang berukuran lebih besar, sehingga sebagian pori tanah akan terisi oleh udara. Sebaliknya tanah yang 
bertekstur halus, maka ruang porinya didominasi oleh pori yang berukuran kecil sehingga sebagian besar porinya diisi oleh air.

\section{Pertumbuhan Kayu Putih}

Tabel 5. Pertumbuhan Kayu Putih (Melaleuca cajuputi sub sp. cajuputi) di Malimbu (M) dan Badung (B)

Table 5. Growth of White Wood (Melaleuca cajuputi sub sp. Cajuputi) in Malimbu (M) and Badung (B)

\begin{tabular}{|c|c|c|c|c|c|c|c|c|c|c|c|c|}
\hline \multirow{3}{*}{ No. Plot Ukur } & \multicolumn{6}{|c|}{ Pertumbuhan Kayu Putih } & \multicolumn{4}{|c|}{$\sum$ Tanaman/Plot } & \multirow{2}{*}{\multicolumn{2}{|c|}{$\begin{array}{c}\text { \% Tumbuh } \\
\text { Kayu Putih/Plot }\end{array}$}} \\
\hline & \multicolumn{2}{|c|}{$\varnothing(\mathrm{cm})$} & \multicolumn{2}{|c|}{$T(m)$} & \multicolumn{2}{|c|}{$V\left(\mathrm{~cm}^{3}\right)$} & \multicolumn{2}{|c|}{ Kayu Putih } & \multicolumn{2}{|c|}{ Total Vegetasi } & & \\
\hline & $\mathbf{M}$ & B & M & B & M & B & $\mathbf{M}$ & B & $\mathbf{M}$ & B & M & B \\
\hline 1 & 1,46 & 3,67 & 1,98 & 3,79 & 266,59 & 3203,4 & 26 & 33 & 32 & 41 & 72,22 & 91,67 \\
\hline 2 & 1,44 & 3,43 & 1,87 & 3,21 & 243,89 & 2377,03 & 22 & 34 & 24 & 37 & 61,11 & 94,44 \\
\hline 3 & 1,4 & 2,88 & 1,75 & 2,86 & 215,09 & 1487,05 & 19 & 29 & 22 & 38 & 52,78 & 80,56 \\
\hline Rata-rata & 1,43 & 3,33 & 1,87 & 3,29 & 241,86 & 2355,83 & 22 & 32 & 26 & 38 & 61,11 & 88,89 \\
\hline
\end{tabular}

Tabel 5 di atas menunjukkan bahwa kualitas pertumbuhan kayu putih di Dusun Badung lebih baik daripada Dusun Malimbu. Rata-rata diameter, tinggi, volume dan jumlah tanaman di Badung sebesar $3,33 \mathrm{~cm}, 3,29 \mathrm{~m}, 2.355,83 \mathrm{~cm}^{3}$ dan 32 tanaman/plot atau 88,89\% tumbuh/plot, sedangkan di Malimbu sebesar 1,43 cm, 1,87 m, 241,85 $\mathrm{cm}^{3}$ dan 22 tanaman/plot atau 61,11\% tumbuh/plot. Jumlah vegetasi lain yang terdapat di sekitar tanaman kayu putih di hutan Malimbu lebih sedikit daripada di hutan Badung. Menurut hasil analisis di atas, persaingan atau perebutan faktor-faktor penunjang atau penyokong pertumbuhan tanaman kayu putih dengan vegetasi lain di lokasi hutan Badung lebih besar dibandingkan di hutan Malimbu. Namun, keberhasilan pertumbuhan tanaman kayu putih di lokasi hutan Badung lebih baik daripada di hutan Malimbu.

\section{Analisis Faktor yang Mempengaruhi Pertumbuhan}

Faktor karakteristik lahan yang diduga mempengaruhi pertumbuhan kayu putih terdiri dari 7 faktor yaitu ketinggian tempat, tekstur tanah (\% fraksi pasir), air tersedia, kadar air tanah kering angin, kedalaman efektif, bulk density dan suhu tanah. Hasil analisis dari 7 faktor $(X)$ tersebut terhadap parameter pertumbuhan diameter kayu putih ( $Y$ ) disajikan pada tabel berikut.

Tabel 6. Hasil Analisis Regresi Linear Berganda Terhadap Diameter Tanaman Kayu Putih Table 6. Results of Multiple Linear Regression Analysis Against Diameter of White Timber Plant

\begin{tabular}{|c|c|c|c|c|c|c|}
\hline \multirow[b]{3}{*}{ Model } & \multirow{2}{*}{\multicolumn{2}{|c|}{$\begin{array}{c}\text { Koefisien Regresi } \\
\text { Tidak Baku }\end{array}$}} & \multirow{3}{*}{$\begin{array}{c}\begin{array}{c}\text { Koefisien } \\
\text { Regresi Baku }\end{array} \\
\text { Beta }\end{array}$} & \multirow[b]{3}{*}{ T hitung } & \multirow{3}{*}{$\begin{array}{l}\text { T tabel } \\
(0,95 ; 13)\end{array}$} & \multirow[b]{3}{*}{ Signifikan } \\
\hline & & & & & & \\
\hline & B & Std. Error & & & & \\
\hline (Konstanta) & -11.428 & 1.830 & & -6.244 & 1.771 & .000 \\
\hline fraksi pasir & -.063 & .004 & -1.226 & -17.310 & 1.771 & .000 \\
\hline suhu tanah & .628 & .076 & .436 & 8.219 & 1.771 & .000 \\
\hline kedalaman efektif & .023 & .005 & .315 & 4.964 & 1.771 & .000 \\
\hline ketinggian tempat & -.003 & .001 & -.139 & -3.355 & 1.771 & .005 \\
\hline
\end{tabular}


Tabel 6 di atas menunjukkan bahwa model persamaan regresi linear berganda yang terbentuk yaitu:

$$
Y=-11,428-0,063 X_{1}+0,628 X_{2}+0,023 X_{3}-0,003 X_{4}
$$

Dari persamaan regresi di atas diketahui bahwa fraksi pasir $\left(X_{1}\right)$, suhu tanah $\left(X_{2}\right)$, kedalaman efektif $\left(X_{3}\right)$ dan ketinggian tempat $\left(X_{4}\right)$ di dalam model berpengaruh nyata pada taraf toleransi $95 \%(\alpha=0,05)$ terhadap diameter $(Y)$. Selanjutnya, hasil analisis untuk parameter tinggi $(Y)$ disajikan pada tabel berikut.

Tabel 7. Hasil Analisis Regresi Linear Berganda Terhadap Tinggi Tanaman Kayu Putih Table 7. Results of Multiple Linear Regression Analysis Against High White Wood Crops

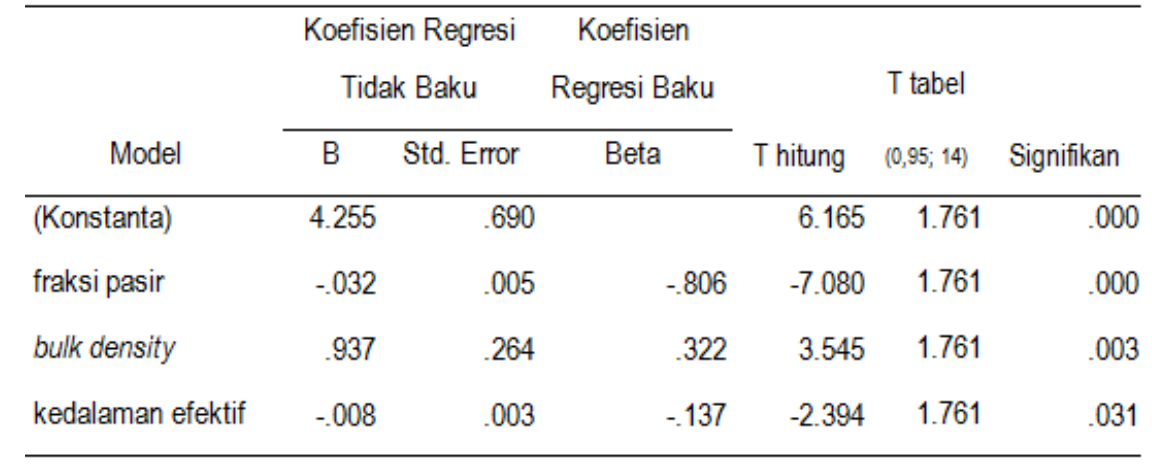

Tabel 7 di atas menunjukkan bahwa model persamaan regresi linear berganda yang terbentuk yaitu:

$$
Y=4,255-0,032 X_{1}+0,937 X_{2}-0,008 X_{3}
$$

Dari persamaan regresi di atas diketahui bahwa fraksi pasir $\left(X_{1}\right)$, bulk density $\left(X_{2}\right)$ dan kedalaman efektif $\left(X_{3}\right)$ di dalam model berpengaruh nyata pada taraf toleransi $95 \%(\alpha=0,05)$ terhadap tinggi $(Y)$. Selanjutnya, hasil analisis untuk parameter volume $(Y)$ disajikan pada tabel berikut.

Tabel 8. Hasil Analisis Regresi Linear Berganda Terhadap Volume Tanaman Kayu Putih

\begin{tabular}{|c|c|c|c|c|c|c|}
\hline \multirow[b]{3}{*}{ Model } & \multirow{2}{*}{\multicolumn{2}{|c|}{$\begin{array}{c}\text { Koefisien Regresi } \\
\text { Tidak Baku }\end{array}$}} & \multirow{3}{*}{$\begin{array}{c}\text { Koefisien } \\
\text { Regresi Baku } \\
\text { Beta }\end{array}$} & \multirow[b]{3}{*}{ T hitung } & \multirow{3}{*}{$\begin{array}{l}\text { T tabel } \\
(0,95 ; 14)\end{array}$} & \multirow[b]{3}{*}{ Signifikan } \\
\hline & & & & & & \\
\hline & B & Std. Error & & & & \\
\hline (Konstanta) & -253.713 & 1181.053 & & -.215 & 1.761 & .833 \\
\hline bulk density & 1996.353 & 575.141 & .449 & 3.471 & 1.761 & .004 \\
\hline fraksi pasir & -37.866 & 8.382 & -.618 & -4.518 & 1.761 & .000 \\
\hline air tersedia & 59.394 & 23.641 & .103 & 2.512 & 1.761 & .025 \\
\hline
\end{tabular}
Table 8. Results of Multiple Linear Regression Analysis Against White Wood Volume

Tabel 8 di atas menunjukkan bahwa model persamaan regresi linear berganda yang terbentuk yaitu:

$$
Y=-253,713+1996,353 X_{1}-37,866 X_{2}+59,394 X_{3}
$$


Dari persamaan regresi di atas diketahui bahwa bulk density $\left(X_{1}\right)$, fraksi pasir $\left(X_{2}\right)$ dan air tersedia $\left(X_{3}\right)$ di dalam model berpengaruh nyata pada taraf toleransi $95 \%(\alpha=0,05)$ terhadap volume $(Y$ ). Dari hasil analisis regresi linear berganda tersebut, dapat disimpulkan bahwa faktor yang secara dominan berpengaruh nyata pada taraf toleransi $95 \%$ terhadap parameter (diameter dan tinggi) tanaman Kayu Putih adalah tekstur tanah (\% fraksi pasir dan kedalaman efektif). Tanah hutan Malimbu bertekstur pasir berlempung sedangkan tanah hutan Badung bertekstur liat dan lempung liat berpasir. Tanah-tanah pasir mempunyai pori-pori kasar lebih banyak daripada tanah liat. Tanah dengan banyak pori-pori kasar akan sulit menahan air sehingga tanaman mudah kekeringan. Kedalaman efektif di Malimbu lebih dangkal daripada di Badung. Tanah dengan kedalaman efektif dangkal menyebabkan terhambatnya perkembangan akar tanaman dan tanah dengan kedalaman efektif dalam akan mempunyai aerasi dan drainase yang baik, serta mampu menyokong perkembangan akar dan tanaman dengan baik (Hardjowigeno, 2011). Oleh karena itu, pertumbuhan tanaman kayu putih di hutan Badung lebih baik daripada di hutan Malimbu.

\section{Kesesuaian Lahan dan Pertumbuhan Kayu Putih}

Kesesuaian lahan aktual untuk kayu putih di Malimbu tergolong Kelas $\mathrm{N}_{1} \mathrm{r}$ (tidak sesuai pada saat ini) dengan faktor pembatas media perakaran (drainase tanah). Sedangkan, di Badung tergolong Kelas $\mathrm{S}_{3} \mathrm{~W}$ dan $\mathrm{S}_{3} \mathrm{wr}$ (sesuai marginal) dengan faktor pembatas pada ketersediaan air (bulan kering) dan media perakaran (drainase tanah). Kecepatan hilangnya air (drainase tanah) pada lokasi penelitian dapat dilihat pada Gambar 3 berikut:

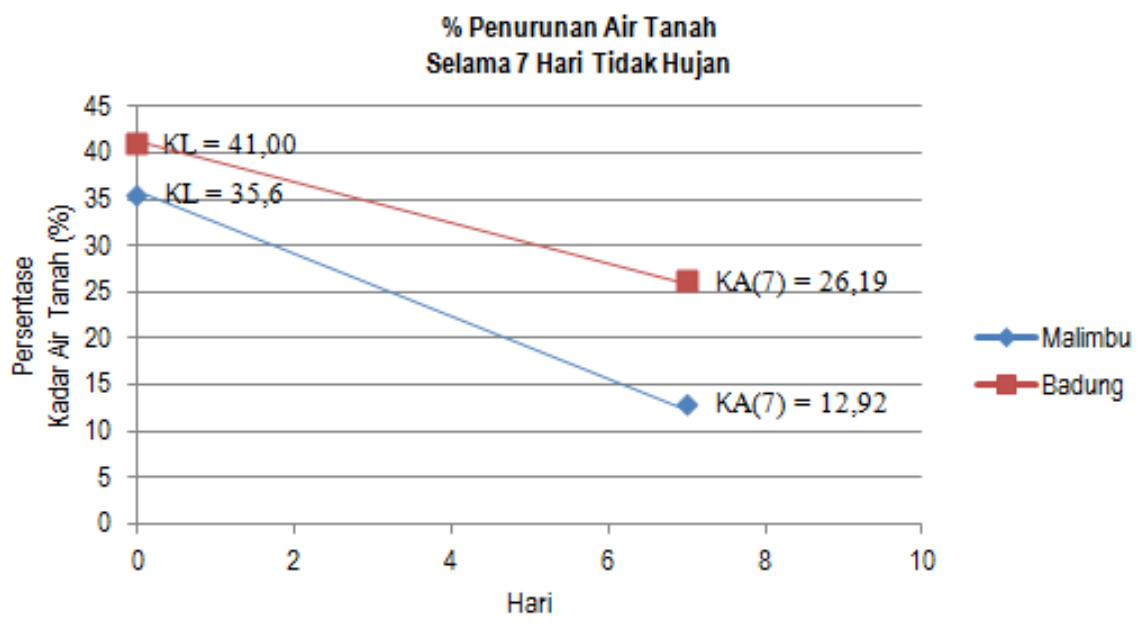

Gambar 3. Penurunan Air Tanah Pada Kondisi Kering Angin Selama 7 Hari Tidak Hujan di Lokasi Penelitian

Figure 3. Decreased Groundwater On Dry Wind Conditions For 7 Days No Rain at Research Sites

Gambar 3 di atas menunjukkan bahwa persentase penurunan air selama 7 hari tidak hujan di lokasi penelitian hutan Malimbu lebih cepat daripada di hutan Badung. Persentase penurunan air di hutan Malimbu sebesar 22,68\% dan di hutan Badung sebesar 14,81\%. Nilai persentase penurunan air tersebut didapat dari hasil pengurangan antara nilai rata-rata kadar air tanah kapasitas lapang $(\mathrm{KL})$ dengan nilai rata-rata kadar air tanah kering angin selama 7 hari tidak hujan (KA). Kondisi penurunan air yang cepat pada tanah Malimbu dipengaruhi oleh tekstur tanahnya (pasir berlempung) sehingga pertumbuhan kayu putih menjadi lambat atau kurang baik. Sedangkan, kondisi penurunan air yang lambat pada tanah Badung dipengaruhi 
oleh tekstur tanahnya (berliat) sehingga pertumbuhan kayu putih menjadi baik dan subur karena mampu menyediakan dan mengikat air di dalam tanah yang berguna bagi tanaman.

\section{KESIMPULAN}

Dari penelitian yang telah dilakukan, dapat disimpulkan hasil sebagai berikut :

1. Kualitas pertumbuhan kayu putih umur 22 bulan pada kawasan hutan Lindung Dusun Badung lebih baik daripada Dusun Malimbu. Rata-rata diameter, tinggi, volume dan jumlah tanaman di Badung sebesar 3,33 cm, 3,29 m, 2.355,83 $\mathrm{cm}^{3}$ dan 32 tanaman/plot. Sedangkan di Malimbu sebesar 1,43 cm, 1,87 m, 241,85 $\mathrm{cm}^{3}$ dan 22 tanaman/plot.

2. Faktor yang berpengaruh nyata pada taraf toleransi $95 \%(\alpha=0,05)$ terhadap pertumbuhan diameter tanaman kayu putih adalah fraksi pasir, suhu tanah, kedalaman efektif dan ketinggian tempat, sedangkan terhadap tinggi kayu putih adalah fraksi pasir, bulk density dan kedalaman efektif.

3. Kesesuaian lahan aktual untuk kayu putih di Malimbu tergolong Kelas $\mathrm{N}_{1} \mathrm{r}$ dengan faktor pembatas media perakaran (drainase tanah). Sedangkan, di Badung tergolong Kelas $\mathrm{S}_{3} \mathrm{~W}$ dan $\mathrm{S}_{3} \mathrm{Wr}$ dengan faktor pembatas pada ketersediaan air (bulan kering) dan media perakaran (drainase tanah).

\section{DAFTAR PUSTAKA}

Arikunto, S. 2006. Prosedur Penelitian Suatu Pendekatan Praktik. Jakarta: Rineka Cipta. Hanafiah, K. A. 2005. Dasar-Dasar Ilmu Tanah. PT. RajaGrafindo Persada. Jakarta.

Hardjowigeno, S. 2003. Ilmu Tanah. CV Akademika Pressindo. Jakarta.

Hardjowigeno, S. 2011. Evaluasi Kesesuaian Lahan dan Perencanaan Tataguna Lahan. Gadjah Mada University Press. Yogyakarta.

KPHL Rinjani Barat. 2011. Peta Penataan Blok dan Rencana Pengelolaan KPHL Rinjani Barat. Balai KPH Rinjani Barat Provinsi Nusa Tenggara Barat.

KPHL Rinjani Barat. 2012. Rancangan Teknis Reboisasi Pengkayaan Hutan Lindung Wilayah KPH Model Rinjani Barat. Balai KPH Rinjani Barat Provinsi Nusa Tenggara Barat.

Ritung, S., Wahyunto, Agus, F., \& Hidayat, H. 2007. Panduan Evaluasi Kesesuaian Lahan dengan Contoh Peta Arahan Penggunaan Lahan Kabupaten Aceh Barat. Balai Penelitian Tanah dan World Agroforestry Centre. Bogor.

Simon, H. 2007. Metode Inventore Hutan. Pustaka Pelajar. Yogyakarta.

Sugiyono. 2013. Metode Penelitian Kuantitatif Kualitatif R \& D. Alfabeta. Bandung.

Syafei, E. S. 1990. Pengantar Ekologi Tumbuhan. Institut Teknologi Bandung. Bandung. 